\title{
WATER QUALITY ANALYSIS OF NAG RIVER IN NAGPUR DISTRICT BY INVESTIGATING PHYSICOCHEMICAL PARAMETERS AND HEAVY METAL CONCENTRATION, MAHARASHTRA (INDIA)
}

\author{
${ }^{1}$ R. G. Gupta, ${ }^{2}$ S. N. Nandeshwar, ${ }^{3}$ A. S. Mahakalkar \\ ${ }^{1}$ Mohota Science College,Sakkaradara Square, Nagpur-09 \\ 2,3Sevadal Mahila Mahavidyalaya,Sakkaradara Square, Nagpur-09 \\ Emails: 1rashmigupta41@rediffmail.com, \\ 2sapnanandeshwar89@gmail.com,3anjaliml@rediffmail.com
}

\begin{abstract}
Disposal of domestic sewage in unlined drains and nalas, cattle farming in Nagpur city areas and dumping of city garbage in the landfill areas without any hydrogeological considerations in rapidly developing Nagpur city have caused the main source of pollution of Nag river water. The main purpose of this study was to analyze the quality of Nag River water with respect to its Physicochemical parameters and concentration of heavy metals i.e. $\mathrm{Cu}, \mathrm{Mn}, \mathrm{Fe}, \mathrm{Zn}, \mathrm{Ni}$ and $\mathrm{Pd}$ to find out its suitability for irrigation purpose. In this study it was found that in the wastewater of Nag River, concentration of Iron and zinc was highest whereas conc. of Nickel and lead was lowest. The present study has concluded that the Water of Nag River is not suitable for irrigation purpose in the month of March-May due to its high concentration of Heavy metals than the permissible limits given by FAO where as it is suitable for irrigation in the month of June-August because in this period due to rain fall the concentration of Heavy metals become low due to dilution.
\end{abstract}

Key words:- Water quality, Heavy metals, Nag River.

\section{Introduction:-}

India is a farming based country, it is well known that in farming irrigation is the most important part but due to Industrialization and urbanization Water is becoming polluted and when this polluted water is used for irrigation in the cultivation of vegetables it affects the suitability of vegetables for consumption purpose. If the water is polluted by high concentration of heavy metals such as $\mathrm{Cu}, \mathrm{Mn}, \mathrm{Fe}, \mathrm{Zn}, \mathrm{Ni}, \mathrm{Pd}$ it goes to soil and then through soil in vegetables, it is accumulated in the edible 
parts of vegetables. Although trace quantities of certain heavy metals such as Chromium, Cobalt, Cupper, Manganese, Zinc etc. are essential micronutrients for higher animals and plant growth but their high concentration may cause health problem [1,2] hence lot of work has been carried out to assess heavy metal bioaccumulation in different vegetables and plants $[3,4,5,6,7,8,9,10]$ which show that heavy metals are non biodegradable and persistent environmental contaminants which are deposited on the surfaces and then absorbed into the tissues of vegetables. Plants take up heavy metals by absorbing them from contaminated soil.

Disposal of domestic sewage in unlined drains and nalas, cattle farming in Nagpur city areas and dumping of city garbage in the landfill areas without any hydrogeological considerations in rapidly developing Nagpur city have caused the main source of pollution of Nag river water as it is the main river which flows through the Nagpur city and passes through Bharatwada, Pawangaon, Asoli, Mahalgaon, Dighori and Pandhurna villages, but due to urbanization and Industrialization it has been found the Nag River is becoming highly polluted by urban waste and heavy metals and serves as the drainage for the city [11].

Most of the village formers are engaged in vegetable cultivation as it is the easiest and cheapest source of water for irrigation to the villagers on the bank of this river so all the fields and farms of these villages are irrigated by the Nag river water. Consumption of vegetables having high concentration of heavy metals it enter the food chain [12] and may lead to the chronic accumulation of heavy metals in the kidney and liver of humans causing disruption of biochemical processes leading to cardiovascular, nervous, kidney and bone disease $[8,13]$.

Therefore it has become essential to find out whether this water is suitable for irrigation of vegetables or not. The purpose of this study was to analyze the quality of wastewater of Nag River which is used for irrigation purpose and to find out its suitability for irrigation with 
reference to its physicochemical parameters and heavy metal concentration i.e. $\mathrm{Cu}, \mathrm{Mn}, \mathrm{Fe}, \mathrm{Zn}, \mathrm{Ni}$ and $\mathrm{Pb}$ in Water.

\section{Material and Methodology:-}

Analytical reagent (AR) grade chemicals and distilled water were used throughout the study. The sampling was carried out according to grab method as given in APHA for the sampling of water [14]. Sampling:-

Water samples were collected from six different villages like Bharatwada, Pawangaon, Asoli, Mahalgaon, Dighori and Pandhurna villages which are along the Nag River. Sampling was made in the summer and rainy season i.e. before spring and after spring in the month of March-April and July-August. The containers used for water sampling were plastic bottles which were thoroughly washed with nitric acid followed by double distilled water. Two samples were collected from each site out of which first sample was analyzed for $\mathrm{pH}$, EC and TDS at the site and second sample was preserved by adding $2 \mathrm{ml}$ of nitric acid in 1 liter water sample for the digestion of heavy metals and it was stored at cold temperature till the further analysis.

All the Physicochemical parameters were analyzes according to the standard methods as given on the APHA while the concentration of heavy metals $(\mathrm{Cu}, \mathrm{Mn}, \mathrm{Fe}, \mathrm{Zn}, \mathrm{Ni}, \mathrm{Pb})$ were analyzed using Atomic Absorption Spectrophotometer (AAS Model No.SL-243, ELICO).

\section{Result and Discussion:-}

The Physicochemical parameters and concentrations of the heavy metals $(\mathrm{ml} / 1)$ in water before and after spring are given in the table 1,2 , 3,4 . 
Table 1. Physicochemical Parameters of water samples before Spring.

\begin{tabular}{|c|c|c|c|c|c|c|}
\hline $\begin{array}{c}\text { Physicochemical } \\
\text { Parameters }\end{array}$ & $\begin{array}{c}\text { Bharatw } \\
\text { ada }\end{array}$ & $\begin{array}{c}\text { Pawang } \\
\text { aon }\end{array}$ & Asoli & $\begin{array}{c}\text { Mahalg } \\
\text { aon }\end{array}$ & $\begin{array}{c}\text { Digh } \\
\text { ori }\end{array}$ & $\begin{array}{c}\text { Pandhu } \\
\text { rna }\end{array}$ \\
\hline pH value & 9.4 & 9.2 & 9.1 & 8.8 & 8.3 & 8.5 \\
\hline E.C. (m mhos/cm3) & 1684 & 1539 & 1249 & 1324 & 1236 & 1282 \\
\hline $\begin{array}{c}\text { Total Dissolved } \\
\text { Solids (mg/l) }\end{array}$ & 983.14 & 893.91 & 6 & 895.64 & $\begin{array}{c}534 . \\
51\end{array}$ & 859.82 \\
\hline Alkalinity (mg/l) & 534.53 & 576.56 & 1 & 642.25 & 87 & 629.19 \\
\hline Calcium (mg/l) & 251.33 & 298.5 & 5 & 435.74 & 8 & 440.84 \\
\hline Magnesium (mg/l) & 85.14 & 98.39 & 6 & 127.78 & 92 & 138.28 \\
\hline Chloride as Cl (mg/l) & 82.24 & 93.93 & 90.51 & 89.62 & 5 & 86.29 \\
\hline Fluoride as F (mg/l) & 0.64 & 0.89 & 0.84 & 0.91 & 0.99 & 0.94 \\
\hline $\begin{array}{c}\text { Total Hardness } \\
(\mathrm{mg} / \mathrm{l})\end{array}$ & 788.92 & 1021.84 & 48 & 834.53 & 48 & 887.82 \\
\hline
\end{tabular}

Table 2. Concentration (mg/l) of Heavy Metals in water samples before spring.

\begin{tabular}{|c|c|c|c|c|c|c|}
\hline Sites & $\mathrm{Cu}$ & $\mathrm{Mn}$ & $\mathrm{Fe}$ & $\mathrm{Zn}$ & $\mathrm{Ni}$ & $\mathrm{Pb}$ \\
\hline Bharatwada & 0.9 & 1.12 & 6.19 & 8.28 & 0.41 & 0.34 \\
\hline Pawangaon & 0.83 & 0.83 & 6.09 & 7.1 & 0.43 & 0.22 \\
\hline Asoli & 0.94 & 0.93 & 4.28 & 7.3 & 0.3 & 0.33 \\
\hline Mahalgaon & 0.63 & 0.91 & 4.67 & 4.62 & 0.51 & 0.23 \\
\hline Dighori & 1.09 & 0.96 & 5.07 & 6.49 & 0.37 & 0.28 \\
\hline Pandhurna & 0.82 & 1.08 & 4.83 & 7.22 & 0.67 & 0.24 \\
\hline Average & 0.8683 & 0.9716 & 5.1883 & 6.835 & 0.4483 & 0.2733 \\
\hline Max. limit by FAO $(\mathrm{mg} / 1)$ & 0.2 & 0.2 & 5 & 2 & 0.2 & 5 \\
\hline
\end{tabular}


Table 3. Physicochemical Parameters of water samples After Spring.

\begin{tabular}{|c|c|c|c|c|c|c|}
\hline $\begin{array}{c}\text { Physicochemical } \\
\text { Parameters }\end{array}$ & $\begin{array}{c}\text { Bharatwa } \\
\text { da }\end{array}$ & $\begin{array}{c}\text { Pawanga } \\
\text { on }\end{array}$ & asoli & $\begin{array}{c}\text { Mahalga } \\
\text { on }\end{array}$ & $\begin{array}{c}\text { Digho } \\
\text { ri }\end{array}$ & $\begin{array}{c}\text { Pandhur } \\
\text { na }\end{array}$ \\
\hline pH value & 8.4 & 8.5 & 8.6 & 8.2 & 7.9 & 7.7 \\
\hline E.C. (m mhos/cm3) & 1392 & 1229 & 1099 & 1020 & 1004 & 1029 \\
\hline $\begin{array}{c}\text { Total Dissolved Solids } \\
(\mathrm{mg} / \mathrm{l})\end{array}$ & 883.20 & 850.14 & 8 & 874.96 & 9 & 839.10 \\
\hline Alkalinity (mg/1) & 509.86 & 549.20 & 2 & 629.38 & 1 & 600.23 \\
\hline Calcium (mg/l) & 229.19 & 281.34 & 1 & 413.49 & 3 & 432.71 \\
\hline Magnesium (mg/1) & 78.29 & 89.37 & 6 & 112.48 & 9 & 103.47 \\
\hline Chloride as Cl (mg/l) & 78.47 & 89.27 & 83.39 & 79.47 & 75.31 & 81.38 \\
\hline Fluoride as F (mg/l) & 0.57 & 0.81 & 0.79 & 0.88 & 0.94 & 0.91 \\
\hline Total Hardness (mg/l) & 720.98 & 1013.47 & 9 & 818.28 & 2 & 879.29 \\
\hline & & & 1289.3 & & 982.3 & \\
\hline BOD (mg/l) & 628.89 & 1212.29 & 28 & 1012.36 & 5 & 738.27 \\
\hline
\end{tabular}

Table 4. Concentration $(\mathrm{mg} / \mathrm{l})$ of Heavy Metals in water samples after spring.

\begin{tabular}{|c|c|c|c|c|c|c|}
\hline Sites & $\mathrm{Cu}$ & $\mathrm{Mn}$ & $\mathrm{Fe}$ & $\mathrm{Zn}$ & $\mathrm{Ni}$ & $\mathrm{Pd}$ \\
\hline Bharatwada & 0.78 & 0.92 & 5.36 & 7.19 & 0.39 & 0.29 \\
\hline Pawangaon & 0.68 & 0.83 & 5.51 & 6.18 & 0.36 & 0.19 \\
\hline Asoli & 0.72 & 0.78 & 3.91 & 6.39 & 0.23 & 0.22 \\
\hline Mahalgaon & 0.61 & 0.76 & 4.13 & 3.89 & 0.42 & 0.18 \\
\hline Dighori & 0.89 & 0.68 & 4.67 & 5.15 & 0.28 & 0.21 \\
\hline Pandhurna & 0.71 & 0.81 & 4.09 & 6.13 & 0.49 & 0.17 \\
\hline Average & 0.7316 & 0.7966 & 4.6116 & 5.8216 & 0.3616 & 0.21 \\
\hline Max. limit by FAO (mg/1) & 0.2 & 0.2 & 5 & 2 & 0.2 & 5 \\
\hline
\end{tabular}

When table 1 was compared with table 3 for the assessment of physicochemical parameters of before spring collected water and after 
spring collected water it has been found that all the physicochemical parameters of after spring collected water were relatively low in concentration as compared to the before spring collected water similarly table 2 was compared with the table 4, the comparison has shown that the concentration of heavy metals with reference to their permissible limits in water before spring is having very high concentration of all the heavy metals as compared to the after spring collected water samples.

When concentration of all the heavy metals in collected water samples were comared to their permissible limits as given by FAO it was found that that the concentration of $\mathrm{Fe}$ and $\mathrm{Zn}$ were in very high in conc. as compared to the maximum permissible limits given by FAO[15]. The conc. of $\mathrm{Pb}$ was below detectable limits and conc. of $\mathrm{Cu}, \mathrm{Mn}$ and $\mathrm{Ni}$ was slightly above the permissible limits. The concentration of Heavy metals among all follows the given order $\mathrm{Zn}>\mathrm{Fe}>\mathrm{Mn}>\mathrm{Cu}>\mathrm{Ni}>\mathrm{Pd}$.

\section{Conclusion:-}

From the above study it has been concluded that the use of this wastewater for irrigation purpose is somewhat suitable after the spring where as it is not suitable before the spring because all the physicochemical parameters and heavy metal concentration of after spring collected water sample were within the range of permissible limits given by FAO for the utilization of irrigation purpose whereas it was very much higher in case of before spring collected water samples, it may be due to the fact that as the spring arrives due to rain fall the concentration of heavy metals become diluted and goes on decreasing due to dilution similarly before spring due to high temperature in summer season it becomes more concentrated.

\section{Acknowledgement:-}

This study was sponsored through University grant commission (UGC), Delhi, India and Dr. Pravin Charde, Principal, Sevadal Mahila Mahavidyalaya, Nagpur for which the authors are extremely grateful. 


\section{References:-}

Yusuf, A. A., Arowolo, T. O. and Bamgbose, O., (2002), "Cadmium, Copper and Nickel levels in vegetables from industrial and residential areas of Lagos city, Nigeria", Global Journal of Environ Science, 1(1), $1-6$

H.k. pandey*, s. gakhar and g. chawla, (2006). heavy metal toxicity in ground water of khajuwala area Located in bikaner division of western rajasthan, Current World Environment Vol. 1(1), 41-44.

john o. jacob, ${ }^{*}$, and samuel e. kakulu,( 2012) . Assessment of Heavy Metal Bioaccumulation in Spinach, Jute Mallow and Tomato in Farms within Kaduna Metropolis, Nigeria. American Journal of Chemistry, 2(1): 13-16.

V. Parth, N.N. Murthy and P. Raj Saxena, August, (2011). Assessment of heavy metal contamination in soil around hazardous waste disposal sites in Hyderabad city (India): natural and anthropogenic implications, E3 Journal of Environmental Research and Management Vol.2(2). pp. 027-034.

AMIYA TIRKEY, P. SHRIVASTAVA and A. SAXENA, (2012). Bioaccumulation of Heavy Metals in Different Components of two Lakes Ecosystem, Current World Environment Vol. 7(2), 293-297 .

S.A. IQBAL AND H.C. KATARIA, (2006). Study of heavy metal contamination in Halali Dam water of Vidisha District near Bhopal (M.P.) India with reference to human health, Current World Environment Vol. 1(1), 61-64.

O.D. OPAlUWA, M. O. AREMU, L. O. OGBO, J. I. MAGAJI, I.E. ODIBA3 and E.R. EKPO, (2012). Assessment of Heavy Metals in Water, Fish and Sediments from UKE Stream, Nasarawa State, Nigeria, Current World Environment Vol. 7(2), 213-220 . 
SUMANTRAO B. BIKKAD and SUNIL R. MIRGANE, (2008). Assessment of heavy metals in ground water of Aurangabad Industrial areas, Current World Enviroment Vol. 3(1), 131-134 .

Kachenko, A. G. and Singh, B., (2006), "Heavy metals contamination in vegetables grown in urban and metal smelter contaminated sites in Australia”, Water, Air and Soil Pollu-tion, 169, 101 - 123.

U.A. Awode, A. Uzairu, M.L. Balarabe, G.F.S. Harrisson and O.J. Okunola, Assessment of Peppers and Soils for Some Heavy Metals from Irrigated Farmlands on the Bank of River Challawa, Northern Nigeria

^ "Nag River Basin".

^ "Heritage status for Nag river".

Sharma, R. J., Agrawal, M. and Marshall, F. M., (2009), "Heavy metals in vegetables collected from production and market sites of a tropical urban area of Indian”, Food and Chemical Technology, 47, 583 591.

APHA, (1992). Standard Methods for the Examination of Water and Wastewater. 16th Edition. American Public Health Association. New York.

FAO/WHO, (2001). Codex Alimentarius Commission. Food additives and contaminants. Joint FAO/WHO Food Standards Programme, ALINORM 01/12A, pp:1-289. 